\title{
Acromegalic Pneumonomegaly: Lung Growth in the Adult
}

\author{
Jerome S. Brody, Aron B. Fisher, Ayhan Gocmen, and \\ Arthur B. DuBois \\ From the Departments of Medicine and Physiology (DGM), University of \\ Pennsylvania School of Medicine and the Veterans Administration \\ Hospital, Philadelphia, Pennsylvania 19104
}

\begin{abstract}
A B S T R A C T Lung size was evaluated with pulmonary function tests in 10 patients with acromegaly, 1 pituitary giant, and 1 patient who had acromegaly but now has hypopituitarism. In the six acromegalic men all lung volumes were increased. The average values and per cent of predicted were total lung capacity 9.1 liters, $139 \%$; functional residual capacity 5.2 liters, $145 \%$; vital capacity 6.0 liters, 134\%; and tissue volume 1.1 liters. There was no evidence of airflow obstruction or air trapping. Anatomic dead space was increased in proportion to the large lung volumes. Lung compliance was increased, averaging 0.43 liters $/ \mathrm{cm} \mathrm{H}_{2} \mathrm{O}$, but lung elastic recoil was normal. These studies show that the lung is involved in the general visceromegaly of acromegaly and that lung size increases in acromegalic men as a result of actual lung growth. Despite the large lung volumes, diffusing capacity was normal suggesting that lung growth resulted from an increase in the size rather than from an increase in the number of alveoli. In contrast to the acromegalic men, lung volumes, anatomic dead space and tissue volume were normal in four acromegalic women, suggesting that sex hormones may modify the effect of growth hormone on the lung. Lung size was large in the pituitary giant but lung volumes were normal according to predicted values based on the patient's great height. Lung volumes were normal in the one male who had been acromegalic but who has been hypopituitary for $21 \mathrm{yr}$. The role of growth hormone in normal postnatal lung growth and in the maintainance of normal lung size remains to be defined.
\end{abstract}

This work was presented in part at the fall meeting of the American Physiological Society, September 1969.

Dr. Gocmen is a Postdoctoral Fellow, Department of Physiology (DGM).

Dr. DuBois is a recipient of a Research Career Award of the National Institute of Health.

Received for publication 18 December 1969 and in revised form 26 January 1970.

\section{INTRODUCTION}

Postnatal lung growth in the human occurs in two main stages (1-3). In the period from birth to about $8 \mathrm{yr}$ lung size increases as new alveoli develop in the walls of poorly differentiated terminal airways (3). From age 8 to early adult life, when lung growth is complete, enlarging alveoli and airways account for further increases in lung size, there being little change in the number of alveoli $(1,2)$. With increasing age there is a gradual loss of lung elasticity (4) but chest wall compliance decreases (5) so that lung size does not change during adult life (4).

This report presents lung function tests in $10 \mathrm{pa}-$ tients with acromegaly, 1 pituitary giant, and 1 former acromegalic who is now hypopituitary. These studies show that the lungs are involved in the general visceromegaly of acromegaly and that in the presence of growth hormone excess the lungs are capable of additional growth during adult life. Furthermore, this type of lung growth is similar to that which occurs during the second stage of normal postnatal lung growth where lung structures enlarge rather than multiply.

\section{METHODS}

Patient material. Patients for this study were drawn from the endocrine clinics of the Veterans Administration Hospital, the Hospital of the University of Pennsylvania, and Philadelphia General Hospital. All subjects were outpatients at the time of study and all were in a clinically stable state. Table I summarizes pertinent clinical information in these patients. 10 patients had acromegaly. Six of the patients were male, four were female. Ages ranged from 43 to $74 \mathrm{yr}$. Four of the subjects were felt to have active disease as judged by clinical criteria of continued growth, increased serum phosphate levels, and elevated growth hormone levels which did not decrease after glucose infusion. Four patients were judged to have partial or total hypopituitarism based on low values of urinary gonadotrophins, urinary hydroxycorticoids, protein-bound iodine, and radioactive iodine uptake and an abnormal response to metapyrone. One patient had a right middle lobectomy $1 \frac{1}{2} \mathrm{yr}$ 
TABLE I

Clinical Data

\begin{tabular}{|c|c|c|c|c|c|c|c|c|}
\hline & $\begin{array}{l}\text { Present } \\
\text { age }\end{array}$ & $\begin{array}{l}\text { Onset } \\
\text { symp- } \\
\text { toms }\end{array}$ & Treatment & $\mathrm{HGH}^{*}$ & $\begin{array}{c}\text { Statusf } \\
\text { acromegaly }\end{array}$ & $\begin{array}{l}\text { Anterior } \ddagger \\
\text { pituitary } \\
\text { function }\end{array}$ & $\begin{array}{l}\text { Complications } \\
\text { of acromegaly }\end{array}$ & $\begin{array}{l}\text { Other } \\
\text { diseases }\end{array}$ \\
\hline $\begin{array}{l}\text { Acromegalic } \\
\text { males }\end{array}$ & $y r$ & & & $\mu g / 100 \mathrm{ml}$ & & & . & \\
\hline $\begin{array}{l}\text { R. N. } \\
\text { G. S. } \\
\text { D. G. }\end{array}$ & $\begin{array}{l}47 \\
45 \\
45\end{array}$ & $\begin{array}{l}1954 \\
1945 \\
1948\end{array}$ & $\begin{array}{l}3500 \text { R } 1954 \\
1500 \text { R } 1956 \\
\text { Partial hypophysectomy } \\
\quad 1964\end{array}$ & $\begin{array}{c}- \\
-\end{array}$ & $\begin{array}{l}\text { Stable } \\
\text { Stable } \\
\text { Stable }\end{array}$ & $\begin{array}{l}\text { Normal } \\
\text { Normal } \\
\text { Hypo }\end{array}$ & $\begin{array}{l}\text { Arthritis } \\
\text { None } \\
\text { None }\end{array}$ & $\begin{array}{l}\text { Peptic ulcer } \\
\text { None } \\
\text { None }\end{array}$ \\
\hline $\begin{array}{l}\text { R. E. } \\
\text { H. T. }\end{array}$ & $\begin{array}{l}69 \\
47\end{array}$ & $\begin{array}{l}1944 \\
1945\end{array}$ & $\begin{array}{l}\text { None } \\
\text { Partial hypophysectomy } \\
1967\end{array}$ & $\overline{52}$ & $\begin{array}{l}\text { Stable } \\
\text { Active }\end{array}$ & $\begin{array}{l}\text { Normal } \\
\text { Hypo }\end{array}$ & $\begin{array}{l}\text { Hypertension } \\
\text { Hypertension }\end{array}$ & $\begin{array}{l}\text { ASHD, COPD } \\
\text { Nephrolithiasis }\end{array}$ \\
\hline F. P. & 47 & 1965 & $4600 \times 1965$ & 4 & Stable & Normal & Weakness & $\begin{array}{r}\text { Lobectomy } 1965 \\
\text { (Hamartoma) }\end{array}$ \\
\hline \multicolumn{9}{|l|}{$\begin{array}{l}\text { Acromegalic } \\
\text { females }\end{array}$} \\
\hline J. H. & 56 & 1946 & None & 50 & Active & Normal & Hypertension & $\begin{array}{l}\text { Adenocarcinoma } \\
\text { colon resected } \\
1968\end{array}$ \\
\hline V. V. & 60 & 1960 & $\begin{array}{l}\text { Partial hypophysectomy } \\
19644500 \mathrm{R}\end{array}$ & 150 & Active & Hypo & $\begin{array}{l}\text { Hypertension } \\
\text { arthritis }\end{array}$ & None \\
\hline P. Y. & 43 & 1960 & 1200 R 1960 & 10 & Active & Hypo & $\begin{array}{c}\text { Hypertension } \\
\text { weakness }\end{array}$ & None \\
\hline B. G. & 74 & 1925 & None & - & Stable & Normal & Hypertension & $\begin{array}{l}\text { Mitral stenosis } \\
\quad \text { (class 1) }\end{array}$ \\
\hline $\begin{array}{l}\text { Former } \\
\text { acromegalic }\end{array}$ & & & & & & & & \\
\hline J. Z. & 44 & 1943 & Pituitary apoplexy 1948 & - & Regressed & Hypo & None & None \\
\hline $\begin{array}{l}\text { Pituitary } \\
\text { giant } \\
\text { L. C. }\end{array}$ & 42 & 1928 & None & - & Stable & Normal & None & \\
\hline
\end{tabular}

ASHD = arteriosclerotic heart disease, COPD = chronic obstructive pulmonary disease.

$*$ HGH $=$ Human growth hormone, measured by radioimmunoassay technique (36). In each instance HGH failed to decrease after a glucose load.

$\ddagger$ For criteria describing clinical status of acromegaly and anterior pituitary function (see Methods).

before study and one patient had chronic obstructive lung disease.

Subject J. Z. had active acromegaly beginning in 1943 but experienced an intracerebral hemorrhage in 1948. Afterwards his acromegalic features began to wane and in 1952 he was diagnosed as being hypopituitary. $\mathrm{He}$ has been treated with cortisone, thyroid hormone, and testosterone since that time, and is in good health. The features of his acromegaly have completely regressed.

Subject L. C. is a $42 \mathrm{yr}$ old female who underwent a period of excessive growth beginning in infancy. Her growth stabilized at $14 \mathrm{yr}$ of age, at which time she reached her present height of 76 inches. The patient has been well since this time and has no features which suggest acromegaly. She had been diagnosed as having gigantism of pituitary origin.

Lung volumes. Functional residual capacity was measured in the sitting position by the helium dilution technique (6). Vital capacity and expiratory reserve volume were also measured in the sitting position. Predicted values are based on height and age, and are taken from the formulae of Goldman and Becklake (7). Anatomic dead space was measured by the single breath nitrogen meter technique of Fowler (8). Measurements were made during quiet respiration at respiratory rates between 16 and 20 per min. The volume of lung that rapidly equilibrates with a soluble inhaled gas (pulmonary tissue volume) was measured by the breath-holding technique of Cander and Forster (9) A gas mixture containing $1 \%$ acetylene, $0.75 \%$ neon, and $0.5 \%$ carbon monoxide in air was inhaled beginning from residual volume and held at total lung capacity for periods ranging from 2.5 to $14 \mathrm{sec}$. Expired gas was collected and analyzed on a gas chromatograph. A total of three or four breath-holding points were measured in each patient. The amount of acetylene absorbed was plotted against time on semilogarithmic paper and a least mean squares line was calculated. Tissue volume was calculated from the intercept of this line at zero time.

Lung mechanics. Forced vital capacity was recorded on a 13.5 liter spirometer. Expiratory flow rates were calculated according to standard techniques (10). Muscle strength was estimated by having the patient attempt to expire and inspire maximally from functional residual capacity against an aneroid manometer. An 18 gauge needle was placed as a leak in the line to prevent pressures which might have been developed in the mouth. Maximum gauge pressure was $40 \mathrm{~mm} \mathrm{Hg}$. Airway resistance was measured by standard techniques in a body plethysmograph (11). Resistance measurements were made at several lung volumes and the reciprocal of airway resistance, airway conductance, was then plotted against lung volumes and compared with the predicted values of Briscoe and DuBois (12). An esophageal balloon was passed into the stomach so that positive pressures were recorded on inspiration, and then pulled back 
into the esophagus approximately $10 \mathrm{~cm}$ from the gastroesophageal junction. The esophageal balloon was filled with $5 \mathrm{ml}$ of air, $4.8 \mathrm{ml}$ of which was then removed. The esophageal balloon was connected to one side of a differential strain gauge, the other side of the strain gauge was connected to a tap at the mouthpiece. After the patient had inspired several times to total lung capacity, he was asked to take a deep breath and transpulmonary pressure was measured after airway interruption at several points during the relaxed expiration from total lung capacity. The pressure volume curves of lung were constructed from the volume changes measured by integration of the pneumotachograph signal and from the transpulmonary pressure measurements. Static lung compliance was calculated as the change in transpulmonary pressure for a $500 \mathrm{ml}$ change in volume above FRC. Uniformity of distribution of ventilation was tested during a single breath of oxygen by the technique of Comroe and Fowler (13).

Pulmonary gas exchange. Single breath diffusing capacity for carbon monoxide was measured at rest and with exercise by the technique of Ogilvie, Forster, Blakemore, and Morton (14). The gas mixture inhaled and the times of breath holding were the same as described under tissue volume above. In five subjects diffusing capacity was measured during exercise after 2 min of pedaling a bicycle ergometer which was set at a work load of $306-612 \mathrm{~kg}-\mathrm{m} /$ min. Duplicate measurements were made at two separate exercise periods. Pulmonary capillary blood flow was calculated from the slope of the semilogarithmic plot of acetylene absorption vs. time. Capillary blood flow was also calculated during exercise from the acetylene absorption after $10 \mathrm{sec}$ of breath holding during exercise and the tissue volume which was determined under resting conditions. In four subjects arterial blood and expired gas were collected at rest and after $2 \mathrm{~min}$ of exercise at $306-612 \mathrm{~kg}-\mathrm{m} / \mathrm{min}$. Blood samples were analyzed in duplicate with a Clark oxygen and Severinghaus carbon dioxide electrode (Radiometer Co., Copenhagen, Denmark). Expired gas was collected in a Tissot spirometer and analyzed with a Scholander $0.5 \mathrm{ml}$ gas analysis apparatus. Alveolar ventilation, physiologic dead space, alveolar-arterial oxygen gradient, oxygen uptake, and carbon dioxide output were calculated by standard methods (15). Standard statistical methods were used in analyzing the data (16).

\section{RESULTS}

\section{Acromegalic males}

Anthropomorphic data (Table II). The acromegalic males were of normal height and weight. The anteriorposterior diameter of the chest cage measured at the second intercostal space was significantly increased in these subjects $(P<0.001)$, averaging $29 \mathrm{~cm}$ vs. a normal of $25 \mathrm{~cm}$ determined in 15 randomly selected hospitalized male patients without lung disease. There was no increase in lateral chest cage diameter but the circumference of the chest measured at residual volume and total lung capacity was increased. Despite the enlarged chest cage, chest cage mobility as judged by the change in chest circumference with the vital capacity maneuver was normal.

TABLE II

Anthropomorphic Data

\begin{tabular}{|c|c|c|c|c|c|c|c|}
\hline & Age & Height & BSA & $\begin{array}{l}\text { Chest } \\
\text { AP }\end{array}$ & $\begin{array}{l}\text { Diameter } \\
\text { LAT }\end{array}$ & $\begin{array}{l}\text { Chest } \\
\text { RV }\end{array}$ & $\begin{array}{l}\text { Circumference } \\
\text { TLC }\end{array}$ \\
\hline & $y r$ & $\mathrm{~cm}$ & & $\mathrm{~cm}$ & $\mathrm{~cm}$ & $\mathrm{~cm}$ & $\mathrm{~cm}$ \\
\hline \multicolumn{8}{|l|}{ Acromegalic males (6) } \\
\hline Mean & 50 & 173 & 1.98 & $29.0^{*}$ & 33.4 & $103.5 \ddagger$ & $109.2 \ddagger$ \\
\hline SD & 9 & 3 & 0.17 & 1.2 & 2.1 & 2.8 & 3.5 \\
\hline \multicolumn{8}{|l|}{ Normal males (15) } \\
\hline Mean & 51 & 171 & 1.87 & 25.0 & 31.3 & 95.6 & 100.6 \\
\hline SD & 13 & 11 & 0.16 & 1.1 & 2.1 & 6.0 & 6.0 \\
\hline \multicolumn{8}{|c|}{ Acromegalic females (4) } \\
\hline Mean & 58 & 167 & 1.91 & $27.1 \ddagger$ & 30.7 & 100.9 & 105.3 \\
\hline SD & 13 & 5 & 0.17 & 1.2 & 2.3 & 10.2 & 11.1 \\
\hline \multicolumn{8}{|l|}{ Normal females (15) } \\
\hline Mean & 38 & 163 & 1.75 & 22.3 & 30.4 & 94.7 & 97.9 \\
\hline SD & 9 & 7 & 0.23 & 3.1 & 3.4 & 10.3 & 10.4 \\
\hline Pituitary giant & 42 & 190 & 2.09 & 23.0 & 31.0 & 89.0 & 96.5 \\
\hline Former acromegalic & 44 & 168 & 1.93 & 26.0 & 36.0 & 110.0 & 113.0 \\
\hline
\end{tabular}

Anterior-posterior and lateral chest wall diameters and chest circumference at residual volume (RV) and total lung capacity (TLC) were measured at the 2 nd intercostal space.

$* P<0.001$.

$\ddagger P<0.05$ for significance of difference from normal. 


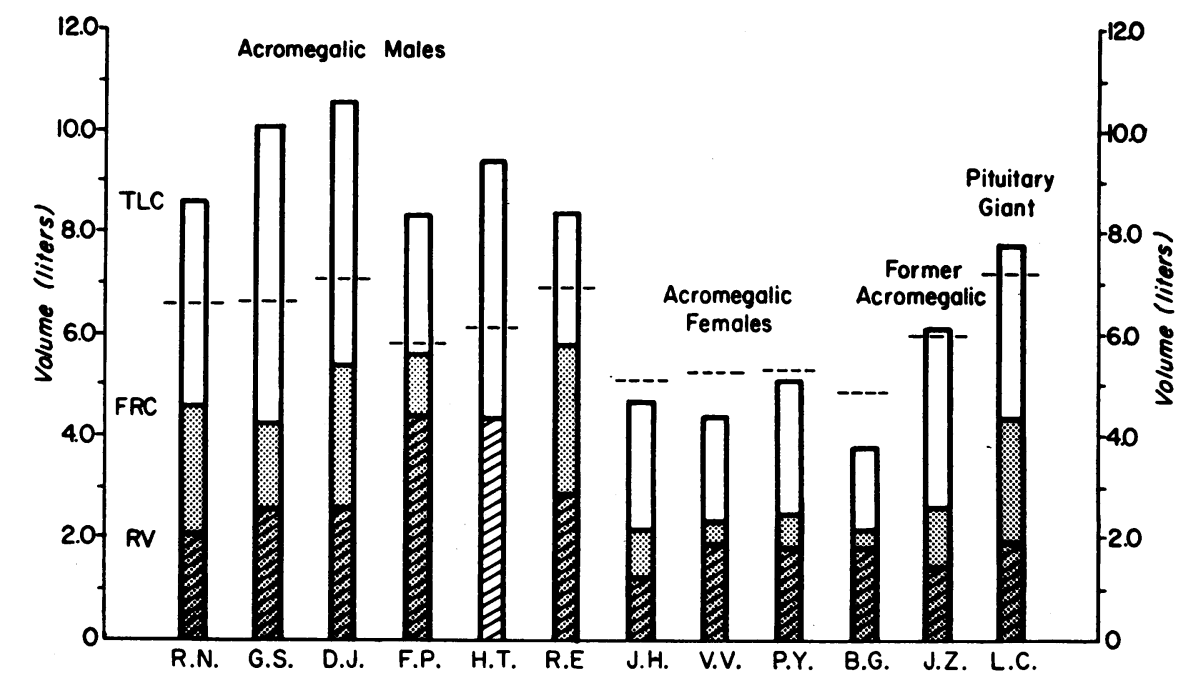

FIGURE 1 Lung volume subdivisions. The height of each bar represents total lung capacity (TLC), the shaded area represents functional residual capacity (FRC), and the cross hatched area represents residual volume (RV). The clear segment of each bar plus the segment which is shaded but without cross hatching represents vital capacity. The interrupted line across each bar represents predicted TLC. The initials at the bottom of the graph identify each patient (see Table I). TLC in patient H. T. was measured from chest radiographs (37).

TABLE III

Lung Mechanics and Tissue Volume

\begin{tabular}{|c|c|c|c|c|c|c|c|c|c|}
\hline & \multirow[b]{2}{*}{$\frac{\mathrm{FEV}_{1}}{\mathrm{FVC}} \times 100$} & & & \multirow[b]{2}{*}{$\mathbf{R}_{\mathbf{A}}$} & \multirow[b]{2}{*}{$\mathrm{C}_{\mathrm{L}}$} & \multicolumn{2}{|c|}{$\mathbf{P}_{\mathrm{TP}}$} & \multirow[b]{2}{*}{$\mathrm{SB}_{\mathrm{N}_{2}}$} & \multirow[b]{2}{*}{$\mathrm{VT}_{\mathrm{T}}$} \\
\hline & & \multicolumn{2}{|c|}{ MVV } & & & At TLC & At FRC & & \\
\hline & $\%$ & $\begin{array}{l}\text { liters/ } \\
\text { min }\end{array}$ & $\begin{array}{c}\% \\
\text { predicted }\end{array}$ & $\begin{array}{l}\mathrm{Cm} \mathrm{H}_{2} \mathrm{O} / \\
\text { liler } / \mathrm{sec}\end{array}$ & $\begin{array}{l}\text { liters } / \\
\mathrm{cm} \mathrm{H}_{2} \mathrm{O}\end{array}$ & $\begin{array}{c}\mathrm{cm} \\
\mathrm{H}_{2} \mathrm{O}\end{array}$ & $\begin{array}{c}\mathrm{cm} \\
\mathrm{H}_{2} \mathrm{O}\end{array}$ & $\begin{array}{c}\% \\
\text { change }\end{array}$ & liters \\
\hline \multicolumn{10}{|l|}{ Acromegalic males } \\
\hline $\begin{array}{l}\text { R. N. } \\
\text { G. S. } \\
\text { D. J. } \\
\text { R. E } \\
\text { H. T. } \\
\text { F. P. }\end{array}$ & $\begin{array}{l}80 \\
76 \\
69 \\
39 \\
79 \\
70\end{array}$ & $\begin{array}{r}182 \\
148 \\
194 \\
39 \\
102 \\
120\end{array}$ & $\begin{array}{r}120 \\
95 \\
120 \\
33 \\
70 \\
75\end{array}$ & $\begin{array}{l}0.95 \\
0.58 \\
1.36 \\
1.48 \\
\overline{0.91}\end{array}$ & $\begin{array}{c}0.39 \\
0.50 \\
0.50 \\
- \\
\overline{0.31}\end{array}$ & $\begin{array}{c}37.4 \\
26.5 \\
29.6 \\
- \\
\overline{28.5}\end{array}$ & $\begin{array}{l}5.8 \\
6.9 \\
4.4 \\
- \\
9.0\end{array}$ & $\begin{array}{l}1.3 \\
1.0 \\
1.0 \\
3.4 \\
2.3\end{array}$ & $\begin{array}{c}1.34 \\
0.84 \\
0.83 \\
1.08 \\
\overline{1.58}\end{array}$ \\
\hline Mean & 69 & 131 & 86 & 1.06 & 0.43 & 30.5 & 6.6 & 1.8 & 1.13 \\
\hline \multicolumn{10}{|l|}{ Acromegalic females } \\
\hline J. H. & 70 & 54 & 69 & 2.70 & - & - & - & - & 0.48 \\
\hline V. V. & 77 & 62 & 84 & - & - & - & - & - & - \\
\hline P. Y. & 88 & 102 & 87 & - & 一 & - & - & 1.6 & 0.60 \\
\hline B. G. & 81 & 56 & 100 & 2.15 & - & - & - & - & 0.54 \\
\hline Mean & 79 & 69 & 85 & 2.42 & - & - & - & - & 0.54 \\
\hline Former acromegalic & 88 & 157 & 107 & 1.50 & 0.25 & 26.1 & 4.4 & 0.8 & 0.44 \\
\hline Pituitary giant & 76 & 181 & 144 & 1.12 & 0.46 & 24.6 & 4.8 & 1.5 & 0.86 \\
\hline
\end{tabular}

$\mathrm{FEV}_{1} / \mathrm{FVC} \times 100=$ per cent of forced vital capacity expired in $1 \mathrm{sec} ; \mathrm{MVV}=$ maximum voluntary ventilation; $\mathrm{R}_{\mathrm{A}}=$ airway resistance; $\mathrm{C}_{\mathrm{L}}=$ lung compliance; $\mathrm{P}_{\mathrm{TP}}=$ transpulmonary pressure measured at total lung capacity (TLC) and functional residual capacity $(\mathrm{FRC}) ; \mathrm{SB}_{\mathrm{N}_{2}}=$ single breath nitrogen test of uneven ventilation; and $\mathrm{V}_{\mathrm{T}}=$ tissue volume. 

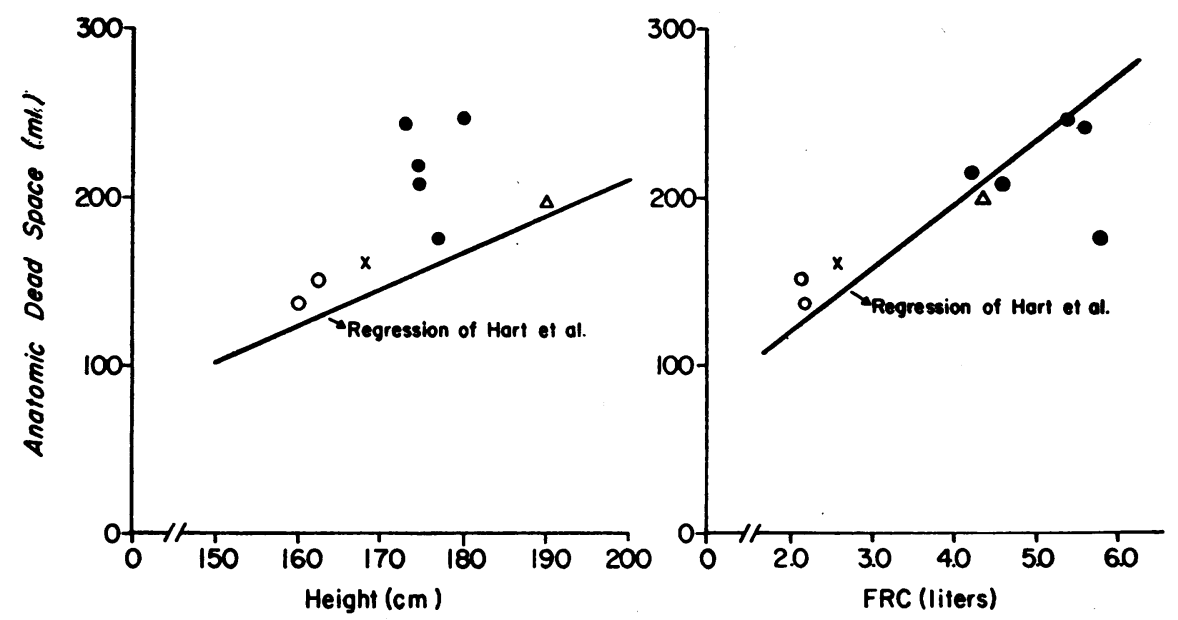

FIGURE 2 Relation of anatomic dead space to height and lung volume. The closed circles represent acromegalic men, the open circles acromegalic women, the $\Delta$ the pituitary giant, and the $\mathrm{X}$ the former acromegalic. The regression is taken from data obtained in normal subjects from 4 to $42 \mathrm{yr}$ of age by Hart, Orzalesi, and Cook (38).

Lung volumes (Fig. 1). All of the subjects had large total lung capacities (121-150\% of predicted), large vital capacities (110-162\% of predicted), and large functional residual capacities (113-161\% of predicted). The ratio of residual volume to total lung capacity was normal except in R. E. who has chronic obstructive lung disease. Tissue volume was increased in five subjects ranging from 0.83 to 1.58 liters (Table III).

Anatomic dead space was increased above values predicted on the basis of the patient's height in four of the five acromegalic males, but was normal in relation to the subject's increased resting lung volume (see Fig. 2) Anatomic dead space was normal in relation to height but small in relation to resting lung volume in patient F. P. who had the right middle lobectomy.

Lung mechanics (Table III). Expiratory flow rates and maximal voluntary ventilation were normal in all acromegalic males with the exception of patient R. E. who had a history compatible with chronic obstructive pulmonary disease. Airway resistance measured at functional residual capacity ranged from 0.58 to $1.48 \mathrm{~cm}$ of water per liter per sec and was normal in relation to

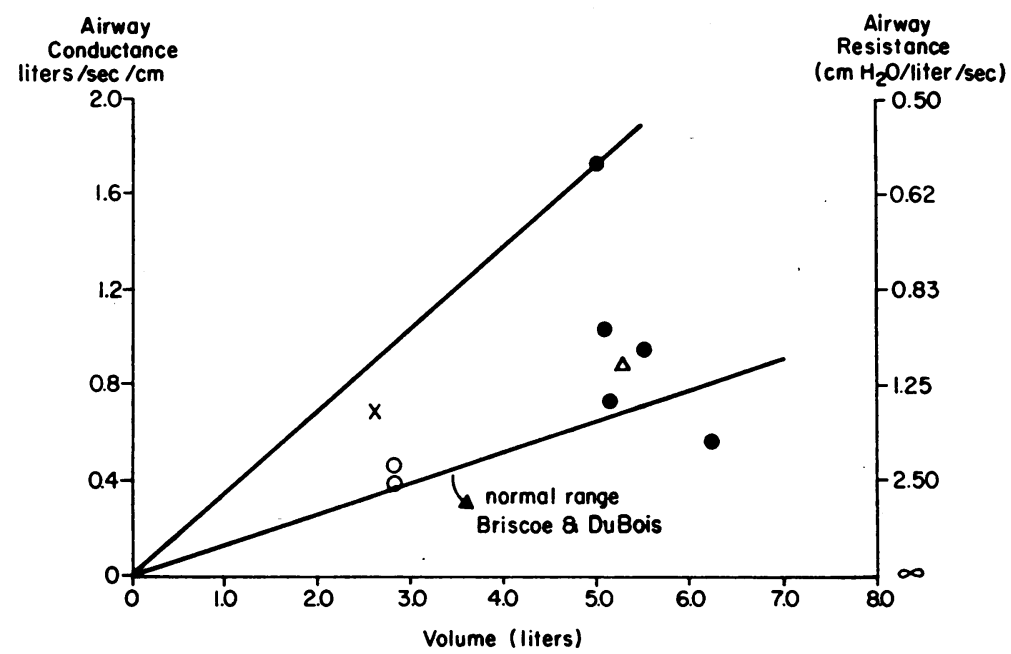

Figure 3 Relation of airway conductance to lung volume. The closed circles represent acromegalic men, the open circles acromegalic women, the $\Delta$ pituitary giant, and the $\mathrm{X}$ the former acromegalic. The solid lines represent the predicted range of normal values determined by Briscoe and DuBois (12). 


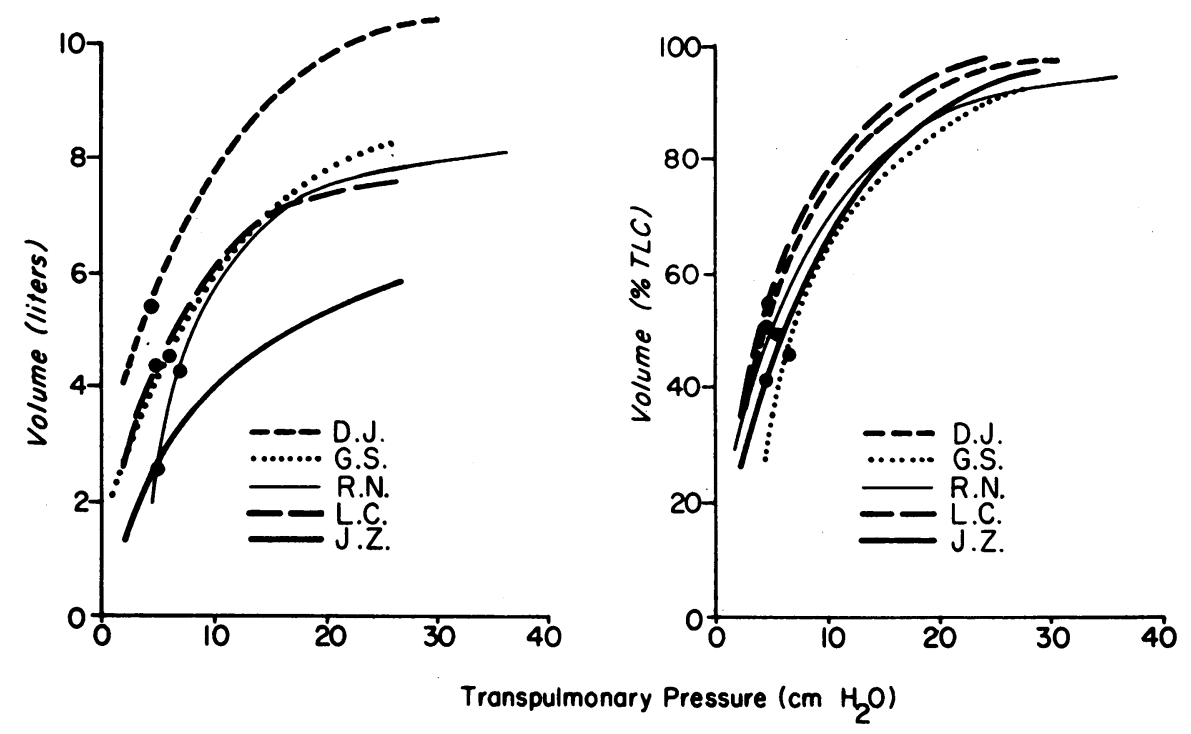

FIgURE 4 Lung pressure volume curves. Initials refer to individual subjects (see

Table I). The closed circles represent transpulmonary pressure at FRC in each subject.

values predicted on the basis of lung volume in all but subject R. E. (see Fig. 3). There was no evidence of muscle weakness. All five subjects tested reached maximum mouth pressures at functional residual capacity of -40 and $+40 \mathrm{~mm} \mathrm{Hg}$ with inspiratory and expiratory effort.

Pressure volume curves of three of the subjects are shown in Fig. 4. Lung compliance was increased in all patients averaging 0.43 liters $/ \mathrm{cm}$ of water. Maximum recoil pressure at total lung capacity ranged from 26.5 to $37.4 \mathrm{~cm}$ of $\mathrm{H}_{2} \mathrm{O}$ with an average of $30.5 \mathrm{~cm}$ of $\mathrm{H}_{2} \mathrm{O}$. Transpulmonary pressure at functional residual ca-

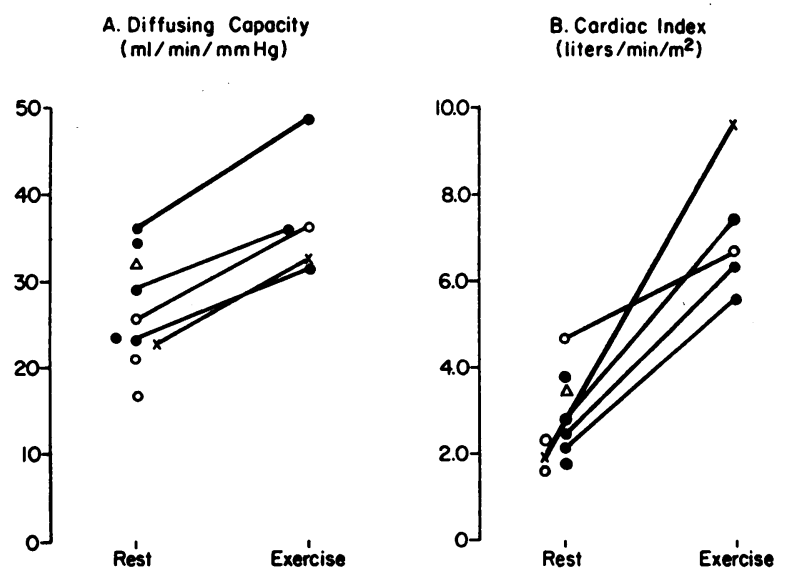

Figure 5 A. Diffusing capacity. B. Cardiac index (pulmonary capillary blood flow/BSA). The closed circles represent acromegalic men, the open circles acromegalic women, the $\Delta$ pituitary giant, and the $\mathrm{X}$ the former acromegalic. pacity was $4.4,5.8$, and $6.9 \mathrm{~cm}$ in the acromegalics with the largest lungs and was $9.0 \mathrm{~cm}$ of $\mathrm{H}_{2} \mathrm{O}$ in $\mathrm{F}$. $\mathrm{P}$. who had a prior lobectomy (Table III).

Gas exchange. Resting diffusing capacity averaged $29 \mathrm{ml} / \mathrm{min}$ per $\mathrm{mm} \mathrm{Hg}$ or $98 \%$ of predicted and ranged from 78 to $117 \%$ predicted (see Fig. 5). In three subjects diffusing capacity increased an average of $32 \%$ after $2 \mathrm{~min}$ of exercise at a work load of $612 \mathrm{~kg}$ $\mathrm{m} / \mathrm{min}$. The cardiac index averaged $2.58 \mathrm{liter} / \mathrm{min}$ per $\mathrm{m}^{2}$ at rest (range $1.77-3.80$ liters/min per $\mathrm{m}^{2}$ ). In three subjects the average increase of cardiac index with exercise was $167 \%$.

Arterial blood studies were performed in three subjects at rest (R.N., G.S., and D.J.) and in two of these subjects with exercise. Minute ventilation averaged 10.1 liters $/ \mathrm{min}$ at rest. Tidal volumes were large, $690 \mathrm{ml}$, as was physiologic dead space, $310 \mathrm{ml}$ (anatomic dead space averaged $227 \mathrm{ml}$ in these subjects). Arterial oxygen tension, arterial carbon dioxide tension, and the alveolar-arterial oxygen gradient were normal at rest averaging $94 \mathrm{~mm} \mathrm{Hg}, 40 \mathrm{~mm} \mathrm{Hg}$, and $5 \mathrm{~mm} \mathrm{Hg}$ respectively and these values did not change significantly during exercise.

\section{Acromegalic females}

Chest anterior-posterior diameter was increased in the acromegalic females although part of the increase could be explained by the slightly higher BSA in the acromegalics. Lateral chest cage diameter and chest circumference were within normal limits.

In contrast to the men, the women had normal lung volumes (Fig. 1), anatomic dead space (Fig. 2), and 
tissue volume (Table III). They had no evidence of muscle weakness or obstructive lung disease and diffusing capacity was within normal limits.

\section{Pituitary giant}

L.C. had normal chest diameter and-circumference (Table II). All lung volumes were large but were normal in relation to values extrapolated from prediction formulae based on height and age (Fig. 1). Anatomic dead space was large but was normal in relation to both height and resting lung volume (Fig. 3). There were no abnormalities in expiratory flow rates or airway resistance, and the lung pressure volume curve was similar to those of the male acromegalics (Fig. 4 and Table III). Diffusing capacity was $32 \mathrm{ml} / \mathrm{min}$ per $\mathrm{mm} \mathrm{Hg}$, $101 \%$ of predicted at rest.

\section{Former acromegalic}

In contrast to the acromegal.c men, J. Z. had a normal chest cage anterior-posterior diameter, and lung volumes, anatomic dead space, tissue volume, lung compliance, and elastic recoil pressures were normal. There was no evidence of airflow obstruction or muscle weakness. Rest and exercise diffusing capacity and cardiac index were also within normal limits.

\section{DISCUSSION}

Acromegalic males. Lung volumes were larger than predicted on the basis of age and height in the six male acromegalics that were studied. We considered the following four possible explanations for the large lungs in these subjects: $(a)$ that growth hormone altered the elastic properties of the lungs thereby dim:nishing elastic recoil and allowing abnormal lung expansion; $(b)$ that the lungs were passively stretched to fill the chest cage which had enlarged as a result of growth hormone induced bone growth; $(c)$ that growth hormone stimulated actual lung growth without concominant growth of the chest cage; and $(d)$ that growth hormone stimulated growth of the lung and chest cage as a unit.

The pressure volume curve of the lung should be different in each of the above situations and should provide a means of determining which of the four explanations is correct. Diminished elastic recoil should result in increased lung compliance $\left(C_{L}\right)$ and decreased transpulmonary pressure $\left(\mathrm{P}_{\mathrm{TP}}\right)$ at total lung capacity (TLC) and functional residual capacity (FRC) much as in the case of pulmonary emphysema $(17,18)$. If the lungs were stretched to fill an enlarged chest cage, $C_{\mathbf{L}}$ would remain normal but $P_{T P}$ at TLC and FRC would be increased much as is the case in some subjects after pneumonectomy (19). If the lungs grew without concominant growth of the chest cage, $C_{L}$ would be increased but $P_{\text {TP }}$ at TLC would be low because the lung would not be fully expanded at the TLC due to the limitations imposed by the chest wall. If the lungs and chest cage had grown as a unit in the acromegalic males and the lungs had retained their normal elastic properties, $C_{L}$ would be increased but $P_{T P}$ would rema:n normal at TLC and FRC. Th:s is the pattern of normal lung growth $(20)$. The lung pressure volume curves in Fig. 4 show that $C_{L}$ was high and $P_{T P}$ was normal at TLC and FRC in the acromegalic males. When the curves are normalized by plotting them as per cent of TLC rather han in terms of absolute volume, the pressure volume curves of the large lung acromegalics, the pituitary giant, and the hypopituitary patient are all similar. These results suggest that actual lung growth occurred in the large lung acromegalics. The pressure volume curve of the pasient who had undergone prior lobectomy differed from the other large lung patients in that $\mathrm{C}_{\mathrm{L}}$ was lower and $\mathrm{P}_{\mathrm{TP}}$ at FRC was higher. But since compliance was higher than would be expected after removal of one lobe (21), both lung growth and stretching of remaining lung tissue after lobectomy occurred in this subject.

Several other physiologic measurements support the occurrence of lung growth in the acromegalic males. ,The normal expiratory air flow rates, and normal airway resistance in relation to lung volume, the absence of any evidence of air trapping, and the lack of uneven distribution of air as measured by the single breath nitrogen test tend to rule out diminished lung elastic recoil as an explanation for the large lungs in these subjects. Anatomic dead space $\left(V_{D}\right)$ was greater than predic'ed on the basis of body height in four of five male acromegalics, much as other lung volumes were increased in relation to predicted values. However, $V_{n}$ in these four subjects was similar to values predicted on the basis of lung size. This implies that the lungs became larger as a result of lung growth since an increase in lung size due to diminished lung elasticity (22) or due to stre $e^{\text {ch }}$ of the lung, as illustrated by measurements of $V_{D}$ at different lung volumes $(8,23)$, would be expected to result in smaller changes in $V_{D}$. Tissue volume $\left(V_{T}\right)$ was elevated in the five male acromegal cs where it was measured averaging almost twice the normal value. It appears unlikely that stretching of the lung or loss of lung elastic recoil would produce an increase in $V_{r}$. The increase in $V_{r}$ implies an increase in lung extravascular water or in pulmonary capillary blood volume. This could have been produced by lung growth or congestive heart failure. However cardiac output and heart size appeared to be normal in these subjects and there was no other evidence of congestive heart failure.

It is possible that the lungs of the acromegalic men were stretched to fill the enlarged chest cage and that 
chronic stress relaxation of the lungs occurred with a resultant decrease in lung elastic recoil. While the phenomenon of acute stress relaxation has been well studied $(24,25)$, little is known of the physiologic effects of chronic stretch or overdistension of the lung. McIlroy and Bates have shown that after pneumonectomy some lungs will gradually lose elastic recoil after being stretched to fill the thoracic space (19). Recent studies of patients with bronchial asthma have suggested that alterations of lung elastic recoil in these patients might be due to chronic stress relaxation of the lung $(26,27)$. The combined effects of lung stretch and gradual loss of elastic recoil might at some point result in large lungs with normal recoil pressure, but this phenomenon would not explain the elevated anatomic dead space and tissue volume in our patients.

Therefore actual lung growth appears to be the most likely explanation for the large lungs of the acromegalic men. Visceromegaly of other organs has been well described in acromegaly $(28,29)$. However, with the exception of two cases reported by Cushing in an autopsy review of acromegaly in 1932 (28), there has been no mention of lung involvement in the excessive visceral growth of acromegaly. Other visceral organs such as the liver, heart, kidney, and pancreas appear to enlarge in acromegaly by increasing cell size (29), although growth hormone administration in experimental animals produces an increase in both cell size and cell number (30). Specific structural units such as the glomerulus of the kidney tend to increase in size rather than in number $(28,29)$.

Normal postnatal lung growth occurs in two major stages; the first primarily associated with an increase in alveolar numbers, the second primarily associated with an increase in alveolar size $(1,2)$. Had growth hormone excess resulted in formation of new alveoli and therefore new surface for gas exchange, diffusing capacity $\left(D_{L}\right)$ should have increased in the acromegalic subjects. However $D_{\mathbf{L}}$ was normal in the acromegalic males averaging $98 \%$ of predicted. The normal $D_{\mathrm{L}}$ suggests that lung growth was associated with increases in alveolar size and that any increase in alveolar volume or in the size of the pulmonary capillary bed was offset by the effects that increased cell size and increased interstitial tissue might have in impeding diffusion. It would appear that lung growth in acromegaly is similar to renal growth in acromegaly where functional units increase in size rather than number and that this form of lung growth is similar to that which occurs during the second stage of normal postnatal lung growth.

Pituitary giant. The studies of lung function in patient L. C. who underwent a period of excessive growth before epiphyseal closure (pituitary gigantism) were similar to those in the acromegalic men who underwent excessive growth after epiphyseal closure. In both, lung compliance was increased while transpulmonary pressure was normal at FRC and TLC. Lung volumes, $V_{D}$, and $V_{T}$ were large in both patients. However since normal values are predicted in part on the basis of height, L. C.'s lung volumes and $\mathrm{V}_{\mathbf{D}}$ were normal in relation to her great height. If $\mathrm{L}$. C. was of normal height as were the patients with acromegaly, her lung volumes would have been large in relation to predicted values. In contrast to the acromegalics her diffusing capacity would also be large in relation to predicted values (125\% of predicted for BSA of 1.75). Since much of L. C.'s excessive lung growth took place during the first stage of lung growth, one might expect an increase in the number of alveoli and an increase in gas exchange units with a resultant increase in $\mathrm{D}_{\mathrm{L}}$. Certainly further studies will be necessary to determine whether growth hormone influences lung structure in a different fashion during the two stages of lung growth.

Acromegalic females. Despite clinical evidence of marked acromegaly and laboratory evidence of active disease as judged by elevated growth homone levels in three subjects, there was no evidence of lung growth in the acromegalic females. The chest cage was only slightly increased in size in these subjects perhaps reflecting increased bone and soft tissue thickness rather than an increase in the internal volume of the chest. Lung volumes, anatomic dead space, and tissue volume were normal. Measurements of $\mathrm{D}_{\mathrm{L}}$, airway resistance, tests of muscle strength, and chest $\mathrm{X}$-rays were also normal, ruling out significant lung disease in the female subjects.

The two large lung cases of acromegaly reported by Cushing were both males and Cushing noted that splanchnomegaly was less pronounced in acromegalic females (28). Recent studies have shown that both estrogens and progestins may alter the severity of acromegaly. Estrogens do not change hormone secretion but appear to antagonize the peripheral metabolic effects of growth hormone (31). Progestins decrease growth hormone levels in patients with acromegaly (32). Our female patients had elevated growth hormone levels and many peripheral metabolic effects of growth hormone excess. It may be that sex hormones have a specific permissive effect, in the case of androgens, or inhibitory effect, in the case of estrogens, on the growth hormone-induced changes in cell size in general or in lung growth in particular.

Former acromegalic. The patient J. Z., who had acromegaly until an episode of pituitary apoplexy in 1948, has lost his acromegalic features, has normal chest cage measurements, and has normal lung volumes and other pulmonary function tests. He has been on replacement treatment of cortisone, thyroid hormone, and androgens since 1952 and is physically well. Complete regression of acromegaly after pituitary apoplexy has 
been reported previously (33). These patients have low or absent growth hormone levels and no growth hormone response to insulin stimulation tests. We have no previous pulmonary function tests in patient $\mathrm{J}$. $Z$. and old chest X-rays had been destroyed. However he did report that his chest was very large when he was acromegalic and that his chest cage gradually returned to normal size and configuration after his intracranial hemorrhage. This suggests that his lung size was large at one time and that lung size had diminished since he became hypopituitary. It is not clear whether growth hormone is necessary for maintaining normal lung size. Renal size and function decrease after hypophysectomy $(34,35)$ and it may be that lung size and perhaps function also decrease in the absence of basal levels of growth hormone.

These studies have suggested a relation between lung structure and function and growth hormone, although many questions regarding growth hormone influence on normal lung growth remain unanswered. Should growth hormone prove to be involved in normal lung growth and should a synthetic preparation become available, it is possible that growth hormone may have potential therapeutic effects in a variety of pulmonary disease states in which lung size is diminished.

\section{REFERENCES}

1. Dunnill, M. S. 1962. Postnatal growth of the lung. Thorax. 17: 329.

2. Emery, J. L., and P. F. Wilcock. 1966. The post-natal development of the lung. Acta Anat. 65: 10 .

3. Boyden, E. A. 1967. Notes on the development of the lung in infancy and early childhood. Amer. J. Anat. 121: 749 .

4. Turner, J. M., J. Mead, and M. E. Wohl. 1968. Elasticity of human lungs in relation to age. J. Appl. Physiol. 25: 664 .

5. Mittman, C., N. H. Edelman, A. H. Norris, and N. W. Shock. 1965. Relationship between chest wall and pulmonary compliance and age. J. Appl. Physiol. 20: 1211.

6. Meneely, G. R., and N. L. Kaltreider. 1949. The volume of the lung determined by helium dilution. Description of the method and comparison with other procedures. J. Clin. Invest. 28: 129.

7. Goldman, H. I., and M. R. Becklake. 1959. Respiratory function tests. Normal values at median altitudes and the prediction of normal results. Amer. Rev. Resp. Dis. 79: 457.

8. Fowler, W. S. 1948. Lung function studies. II. The respiratory dead space. Amer. J. Physiol. 154: 405.

9. Cander, L., and R. E. Forster. 1959. Determination of pulmonary parenchymal tissue volume and pulmonary capillary blood flow in man. J. Appl. Physiol. 14: 541.

10. Kory, R. C., R. Callahan, H. G. Boren, and J. C. Syner. 1961. The Veterans Administration-Army cooperative study of pulmonary function. I. Clinical spirometry in normal men. Amer. J. Med. 30: 243.

11. DuBois, A. B., S. Y. Botelho, and J. H. Comroe, Jr. 1956. A new method for measuring airway resistance in man using a body plethysmograph: values in normal subjects and in patients with respiratory disease. J. Clin. Invest. $35: 327$.

12. Briscoe, W. A., and A. B. DuBois. 1958. The relationship between airway resistance, airway conductance and lung volume in subjects of different age and body size. $J$. Clin. Invest. 37: 1279.

13. Comroe, J. H., Jr., and W. S. Fowler. 1951. Lung fun=tion studies. VI. Detection of uneven alveolar ventilation during a single breath of oxygen. Amer. J. Med. 10: 408.

14. Ogilvie, C. M., R. E. Forster, W. S. Blakemore, and J. W. Morton. 1957. A standardized breath holding technique for the clinical measurement of the diffusing capacity of the lung for carbon monoxide. J. Clin. Invest. 36: 1.

15. Comroe, J. H., Jr., R. E. Forster, A. B. DuBois, W. A. Briscoe, and E. Carlsen. 1962. The Lung; Clinical Physiology and Pulmonary Function Tests. Year Book Medical Publishers, Inc., Chicago. 2nd edition. 390.

16. Snedecor, G. W., and W. G. Cochran. 1967. Statistical Methods. Iowa State University Press, Ames. 6th edition. 593.

17. Christie, R. V. 1934. The elastic properties of the emphysematous lung and their clinical significance. J. Clin. Invest. 13: 295 .

18. Macklem, P. T., and M. R. Becklake. 1963. The relationship between the mechanical and diffusing properties of the lung in health and disease. Amer. Rev. Resp. Dis. $87: 47$.

19. McIlroy, M. B., and D. V. Bates. 1956. Respiratory function after pneumonectomy. Thorax. 11: 303.

20. Cook, C. D., P. J. Helliesen, and S. Agathon. 1958. Relation between mechanics of respiration, lung size and body size from birth to young adulthood. J. Appl. Physiol. 13: 349.

21. Frank, N. R., A. A. Siebens, and M. M. Newman. 1959. The effect of pulmonary resection on the compliance of human lungs. J. Thorac. Cardiovasc. Surg. 38: 215.

22. Fowler, W. S. 1950. Lung function studies. V. Respiratory dead space in old age and pulmonary emphysema. J. Clin. Invest. 29: 1439.

23. Birath, G. 1959. Respiratory dead space measurements in a model lung and healthy human subjects according to the single breath method. J. Appl. Physiol. 14: 517.

24. Hughes, R., A. J. May, and J. G. Widdicombe. 1959. Stress relaxation in rabbits' lungs. J. Physiol. (London). 146: 85.

25. Sharp, J. T., F. N. Johnson, N. B. Goldberg, and P. Van Lith. 1967. Hysteresis and stress adaptation in the human respiratory system. J. Appl. Physiol. 23: 487.

26. Woolcock, A. J., and J. Read. 1968. The static elastic properties of the lungs in asthma. Amer. Rev. Resp. Dis. 98: 788.

27. Finucane, K. E., and J. H. Colebatch. 1969. Elastic behavior of the lung in patients with airway obstruction. J. Appl. Physiol. 26: 330 .

28. Cushing, H., and L. M. Davidoff. 1927. The pathological findings in four autopsied cases of acromegaly with a discussion of their significance. Monograph of the Roskefeller Institute for Medical Research. No. 22.

29. Daughaday, W. H. 1968. The adenohypophysis. In Textbook of Endocrinology. R. H. Williams, editor. W. B. Saunders Company, Philadelphia. 4th edition. 2: 27. 
30. Brasel, J. A., and D. B. Cheek. 1968. The effect of growth hormone on the cellular mass of hypopituitary dwarfs. In Growth Hormone. Proceedings of 1st International Symposium. A. Pecile and E. E. Müller, editors. Excerpta Medica Foundation, New York. 433.

31. Schwartz, E., E. Echemendia, M. Schiffer, and V. A. Panariello. 1969. Mechanism of estrogenic action in acromegaly. J. Clin. Invest. 48: 260.

32. Lawrence, A. W. 1969. Medical treatment of acromegaly with progestins. Clin. Res. 17: 289.

33. Taylor, A. L., J. L. Finster, P. Raskin, J. B. Field, and D. H. Mintz. 1968. Pituitary apoplexy in acromegaly. J. Clin. Endocrinol. Metab. 28: 1784.

34. Astarabadi, T. 1962. The regression in size of the hyper- trophic remaining kidney after hypophysectomy in rats. Quart. J. Exp. Physiol. Cog. Med. Sci. 47: 93.

35. Falkheden, T. 1963. Renal function following hypophysectomy in man. Acta Endocrinol. 42: 571.

36. Root, A. W., R. L. Rosenfield, A. M. Bongiovanni, and W. R. Eberlein. 1967. The plasma growth hormone response to insulin-induced hypoglycemia in children with retardation of growth. Pediatrics. 39: 844 .

37. Loyd, H. M., S. T. String, and A. B. DuBois. 1966. Radiographic and plethysmographic determination of total lung capacity. Radiology. 86: 7 .

38. Hart, M. C., M. M. Orzalesi, and C. D. Cook. 1963. Relation between anatomic respiratory dead space and body size and lung volume. J. Appl. Physiol. 18: 519. 